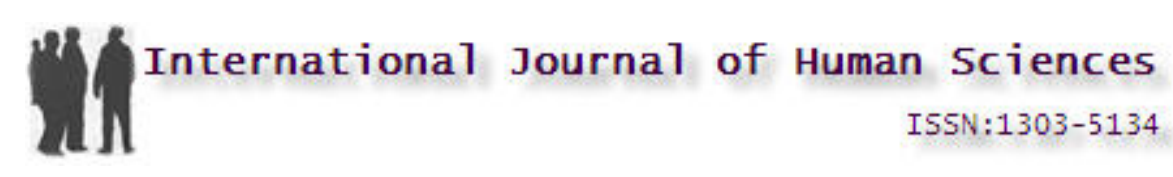

Volume: 5 Issue: 2 Year: 2008

\title{
Assessment of the Turkish Local e-Governments: An empirical study
}

\author{
Aykut ARSLAN*
}

\begin{abstract}
In this research, we first evaluated the current practices of the Turkish local e-governments. Then, building upon an earlier study of local e-governments in Europe (Key Elements for Electronic Local Authorities' Networks [KEeLAN], 2002), we compared the Turkish local e-government stages with their European counterparts to give a broader perspective. The basic framework focuses on the evaluation of current practices on the supply side (government), rather than the demand side (citizen). The emphasis of this research is on the evaluation of each web site in terms of nine basic public services (additional sub-services available) comprised of policy making, economic development, personal documents, credit and loans/financial support, education, building permits, environment, culture and leisure, and information dissemination. It is assumed that at least four of those services (randomly) are supplied in a local context among the Member Countries, including Turkey. We suggest the results might provide a deeper understanding of local e-governments in Turkey and lend support to advances in this under-researched area.
\end{abstract}

Keywords. Local government, local e-government, e-government, e-municipality, eservice, e-Europe, e-Turkey

\footnotetext{
* PhD, Naval Training Center Command
} 


\section{Türk e-Yerel Yönetimlerinin analizi: Ampirik bir araştırma}

\section{Özet}

Bu araştırmada ilk olarak Türk e-yerel yönetimlerinin mevcut durumunu değerlendirdik. Ardından, daha önce Avrupa e-yerel yönetimlerinin incelenmesinde kullanılan verilerden yola çıkarak Türk e-yerel yönetimlerini karşılaştırdık. Araştırmanın kısıtlarından biri değerlendirmenin talepten ziyade vatandaşa arz açısından yapılmasıdır. Buradaki amaç yerel yönetimlerin mevcut web sayfalarında sundukları politika, ekonomik gelişme, kişisel belgeler, kredi ve borç ödeme/finansal destek, eğitim, inşaat izni, çevre, kültür ve sosyal faaliyetler ile bilgi sunumu gibi dokuz temel hizmetin (alt hizmetler de dâhil olmak üzere) tek tek beş gelişim aşamasından ( 0-5) hangi seviyede olduklarını tespit etmektir. Varsayımlardan bir tanesi bu dokuz temel hizmet arzının rastsal bir şekilde tüm Avrupa ülkelerinde (Türkiye'de dahil) yerel yönetimlerce yapılıyor olmasıdır. Bulgularımızın ülkemizde pek az araştırılmış bu alanda yeni bir ivme kazandıracağına inanıyor ve Türk yerel yönetimlerinin elektronik devlete dönüşümünde kıyaslama ile hangi seviyede ve ne aşamada olduklarını ortaya koyuyoruz.

Anahtar Sözcükler: yerel yönetim, e-yerel yönetim, e-devlet, e-belediye, e-hizmet, eAvrupa, e-Türkiye, kıyaslama. 


\section{Introduction}

Understanding which factors affect adoption of e-government initiatives on the local level is important, both from academic and practical perspectives. Local government has the most direct effect on citizens' lives. Griffin et al. (2004) argues that the local authority performs various roles. The most significant of these are being service providers, regulators, strategic planners and advocates for the local community. Pavlichev (2004) points out the importance of local authority for the average citizen by personal interactions. The most frequent relationship occurs with government at this level (European Union [EU], 2003). The famous Maastricht Treaty declared that the European Union was founded on the decisions taken as closely as possible to the citizens while highlighting the importance of the local democracy (the Scottish Office, 1998). Even to some sources (Austrian Association of Communities [AAC], 2003) the strength of the local governments have been associated with the driving force of European Union.

Turkey has a highly centralized administration framework (United Nations Public Administration [UNPAN] Report, 2006). This centralized attitude is also explicit in her approach to local governments (Interoperable Delivery of European eGovernment Services to public Administrations, Business and Citizens [IDABC] Factsheet, 2006). It was not until 2006 that the national strategy included local administration for the very first time through a wider perspective (Strategy Implementation Guide [SIG], 2006). There was even an implementation reference for Local e-Democracy. Lack of coordination and cooperation among the local and central actors, duplication of individual efforts, lack of qualified personnel, or islands of automation has been playing a great role in the development of the local e-government initiatives of Turkey. On the other hand, the academic contribution also lacks in this respect by providing concrete research findings.

In this research, we first evaluated the current practices of Turkish local e-governments. Then, building upon an earlier study of local e-governments in Europe (Key Elements for Electronic Local Authorities' Networks [KEeLAN], 2002), we compared the Turkish local e-government stages with their European counterparts to give a broader perspective. The basic framework focuses on the evaluation of current practices on the supply side (government), rather than the demand side (citizen). The emphasis of this research is on the evaluation of each web site in terms of nine basic public services (additional sub-services available) comprised of policy making, economic development, personal documents, credit and loans/financial support, education, building permits, environment, culture and leisure, 
and information dissemination. It is assumed that at least four of those services (randomly) are supplied in a local context among the Member Countries, including Turkey. We suggest the results might provide a deeper understanding of local e-governments in Turkey and lend support to advances in this under-researched area.

\section{E-government Status of Turkey: a General Outlook}

Despite some fruitless attempts over the last 15 years towards de-concentration and decentralization, Turkey's unitary system is still comprised of a highly centralized government and administrative structure. The country is divided into 81 special provinces each of which is headed by a governor appointed by the national government. The provinces are sub-divided into a total of 850 districts. In addition to the provincial units of central government departments, there are three layers of local authorities: Special provincial administrations, municipalities and villages.

With the term "local governments" in this paper, we refer to municipalities. Municipalities are one of the most important local administrative units along with special provincial administrations and villages as well as different unions of these local representatives. Almost $79,5 \%$ of the whole population resides in the boundaries of municipalities (Bindebir, 2004:1). But through the view of efficiency, subsidiary and some other additional factors not only did villages become over pacified; but also the special provincial administrations lost their entity of locality and became the extensions of central governments (Aydemir, 2003); so to say, “ much weaker” than ever (Kavruk, 2004:200). Due to strict administrative tutelage system and control of the central government, almost all of the basic service provisions have been taken from the responsibility of local governments. According to Kavruk (2004:200) "today approximately 85 \% of the public services are provided by the central government organizations” whereas local governments provide only " $15 \%$ ”. This is contradictory to the Member States' public sector provisions in general because the majority of the tasks are handled in the local level around Europe (EU, 2003). Some of these services in Turkey however, were accomplished on the local level in the past. Despite the low service provisions on local levels, overlapping of services is also common in some fields of tasks among the related parties between local and central administrations (Kavruk, 2004).

Recent statistics indicates that $21.1 \%$ of the population uses the Internet (http://www.internetworldstats.com/eu/tr.htm, as of Sept. 2006). According to the results of Information and Communication Technology (ICT) Usage Survey on Households and 
Individuals carried out by Turkish Statistical Institution [TurkStat] (2005) 8.66 \% of households have access to the Internet at home. It was $7.02 \%$ in the same period of the previous year.

Regardless of the individual efforts for years with different names and acronyms, the eTurkey initiatives were assembled under one coordination mechanism. The leadership was assumed by a deputy prime minister and the State Planning Organization. The name became known as "e-Transformation Turkey” that took place under the Public Administration Reform heading. As an EU candidate country, Turkey declared e-government initiatives would be aligned with e-Europe framework (UNPAN Report, 2006). The e-Europe framework is comprised of 20 basic services either supplied on local level or central level. As of the end of the year 2006, $53 \%$ of the services are provided online. As for the maturity levels, among those online services, $42 \%$ are at stage one; $29 \%$ is at stage two; $24 \%$ is at stage three; and $5 \%$ is at stage four. But these indices constitute only central government services (Performance Report, 2006); local governments were not included because they were not measured.

\section{E-government Assessment Methodologies}

Assessment is vital to discovering the current state of e-government development, working out the extent to which objectives within various strategies and action plans have been reached, ascertaining strengths and weaknesses, shaping new guidelines, looking for examples of best practices and finally comparing different e-government organizations at the national and international levels.

Owing to the very nature of rapid evolution in this field, and disagreements on core definitions (Löfstedt, 2005) e-government initiatives around the world are trying to develop structured assessment methodologies that will fit into the context of the countries where there are established.

The vast literature of the e-government research map sees e-government as an incremental progression grounded on technological and organizational sophistication. Table 1 summarizes these incremental approaches. The ranges of sophistication change from 3 to 6 different stages. 
Arslan, A. (2008). Assessment of the Turkish Local e-Governments: An empirical study. International Journal of Human Sciences [Online]. 5:2. Available: http://www.insanbilimleri.com

\begin{tabular}{|c|c|c|}
\hline Stages & Descriptions & Reference \\
\hline $\begin{array}{l}\text { Stage 1: Publish } \\
\text { Stage 2: Interact } \\
\text { Stage 3: Transact }\end{array}$ & $\begin{array}{l}\text { 1. Information about activities of government available online. } \\
\text { 2. Enables citizens to have simple interactions with their } \\
\text { governments such as sending e-mail or 'chat rooms'. } \\
\text { 3. Provides citizens with full benefits from transactions over } \\
\text { the Internet, such as applying for programmes and services, } \\
\text { purchasing licences and permits. }\end{array}$ & Howard (2001) \\
\hline $\begin{array}{l}\text { Stage 1: Information } \\
\text { Stage 2: Interaction } \\
\text { Stage 3: Transaction } \\
\text { Stage 4: Integration }\end{array}$ & $\begin{array}{l}\text { 1. Delivery of government services online. One-way } \\
\text { communication between government and citizens. } \\
\text { 2. Simple interaction between citizens and governments. } \\
\text { 3. Services that enable transactions of value between citizens } \\
\text { and government. } \\
\text { 4. Integration of services across the agencies and departments } \\
\text { of government. }\end{array}$ & $\begin{array}{l}\text { Chandler and } \\
\text { Emanuels (2002) }\end{array}$ \\
\hline $\begin{array}{l}\text { Stage 1: Cataloguing } \\
\text { Stage 2: Transaction } \\
\text { Stage 3: Vertical } \\
\text { integration } \\
\text { Stage 4: Horizontal } \\
\text { integration }\end{array}$ & $\begin{array}{l}\text { 1. Creating websites and making government information and } \\
\text { services available online. } \\
\text { 2. Enables citizens to interact with their governments } \\
\text { electronically. } \\
\text { 3. Focuses on integrating disparate at different levels. } \\
\text { 4. Focuses on integration of government services for different } \\
\text { functions horizontally. }\end{array}$ & $\begin{array}{l}\text { Layne and Lee } \\
\text { (2001) }\end{array}$ \\
\hline $\begin{array}{l}\text { Stage 1: Emerging } \\
\text { Stage 2: Enhanced } \\
\text { Stage 3: Interactive } \\
\text { Stage 4: Transactional } \\
\text { Stage 5: Seamless or } \\
\text { fully } \\
\text { integrated }\end{array}$ & $\begin{array}{l}\text { 1. Creating a government website with limited / static } \\
\text { information. } \\
\text { 2. Updating information regularly. } \\
\text { 3. Provides users with reasonable levels of interaction enabling } \\
\text { them to download forms. } \\
\text { 4. Enables users to complete transactions such as obtaining } \\
\text { visas, licenses, passports, birth and death records, etc. online } \\
\text { safely and securely. } \\
\text { 5. Provides services across administrative and departmental } \\
\text { lines with the highest level of integration. }\end{array}$ & $\begin{array}{l}\text { UN - DPEPA } \\
\text { Report (2002) }\end{array}$ \\
\hline $\begin{array}{l}\text { Stage 1: Information } \\
\text { publishing } \\
\text { Stage 2: Official' two- } \\
\text { way } \\
\text { transactions } \\
\text { Stage 3: Multi- } \\
\text { purpose portals } \\
\text { Stage 4: Portal } \\
\text { personalization } \\
\text { Stage 5: Clustering of } \\
\text { common } \\
\text { services } \\
\text { Stage 6: Full } \\
\text { integration and } \\
\text { enterprise } \\
\text { transformation }\end{array}$ & $\begin{array}{l}\text { 1. Creates websites by departments and agencies. One-way } \\
\text { communication. } \\
\text { 2. Enables customers to have electronic interaction with } \\
\text { government services such as renewing television licenses and } \\
\text { paying parking tickets. } \\
\text { 3. Enables customers to obtain government services and } \\
\text { information from a single point. } \\
\text { 4. Provide customers with opportunities to customize portals } \\
\text { according to their need. } \\
\text { 5. With portals becoming better, government departments will } \\
\text { disappear where government will seek to gather common } \\
\text { services to hurry the process of delivery. } \\
6 \text {. Government departments will disappear others will appear; } \\
\text { some departments will keep the same names but become } \\
\text { entirely different internally. }\end{array}$ & $\begin{array}{l}\text { Deloitte Research } \\
\text { cited in Silcock } \\
\text { (2001) }\end{array}$ \\
\hline $\begin{array}{l}\text { Stage 1: Billboard } \\
\text { Stage 2: Partial- } \\
\text { service delivery } \\
\text { Stage 3: Integrated } \\
\text { service delivery } \\
\text { Stage 4: Interactive } \\
\text { democracy }\end{array}$ & $\begin{array}{l}\text { 1. Displaying information on the web. } \\
\text { 2. Manipulating information databases. } \\
\text { 3. Integrating agency sites. } \\
\text { 4. Government interacting with citizens in momentous ways. }\end{array}$ & West (2004) \\
\hline Stage 1. Information & 1. This is the most basic form of e-government, which & Moon (2002) \\
\hline
\end{tabular}


Arslan, A. (2008). Assessment of the Turkish Local e-Governments: An empirical study. International Journal of Human Sciences [Online]. 5:2. Available: http://www.insanbilimleri.com

\begin{tabular}{|c|c|c|}
\hline $\begin{array}{l}\text { dissemination } \\
\text { Stage } 2 \text {. Two-way } \\
\text { communication } \\
\text { Stage } 3 \text {. Service and } \\
\text { financial transaction } \\
\text { Stage } 4 \text {. Vertical and } \\
\text { horizontal integration } \\
\text { Stage } 5 \text {. Political } \\
\text { (citizen) participation }\end{array}$ & $\begin{array}{l}\text { disseminates information by simply posting it on the web sites. } \\
\text { 2. Request and response. Interaction occurs between } \\
\text { governments and users. } \\
\text { 3. Transactions occur both between governments and } \\
\text { individuals (e.g. obtaining visa), and between governments and } \\
\text { businesses (i.e. ordering office facilities). } \\
\text { 4. This stage refers to integrating separate systems at different } \\
\text { levels (vertical) and from different departments (horizontal). } \\
\text { 5. Political participation. Promotion of political participation } \\
\text { through services such as online voting and surveys. }\end{array}$ & \\
\hline $\begin{array}{l}\text { Stage } 0 . \\
\text { Stage } 1 . \\
\text { Stage } 2 . \\
\text { Stage } 3 .\end{array}$ & $\begin{array}{l}\text { 0. Information about a given topic does not exist on the } \\
\text { website. } \\
\text { 1. Information about a given topic exists on the website } \\
\text { (including links to other information and e-mail addresses). } \\
\text { 2. Downloadable items are available on the website (forms, } \\
\text { audio, video, and other one-way transactions, popup boxes). } \\
\text { 3. Services, transactions, or interactions can take place } \\
\text { completely online (credit card transactions, apply for permits, } \\
\text { searchable databases, use of cookies, digital signatures, } \\
\text { restricted access). }\end{array}$ & $\begin{array}{l}\text { Holzer and Kim } \\
\text { (2003) }\end{array}$ \\
\hline $\begin{array}{l}\text { Stage } 0 . \text { No presence } \\
\text { Stage } 1 \text {. Information } \\
\text { Stage } 2 \text {. Interaction } \\
\text { Stage } 3 \text {. Two-way } \\
\text { interaction } \\
\text { Stage } 4 \text {. Transaction } \\
\text { Stage } 5 \text {. Service } \\
\text { Integration }\end{array}$ & $\begin{array}{l}\text { 0. No presence. } \\
\text { 1. Online information about public service. } \\
\text { 2. Downloading forms. } \\
\text { 3. Processing of forms, including authentication. } \\
\text { 4. Full case handling (decision and delivery with payment). } \\
\text { 5. Online service delivery enabled by means of a secured } \\
\text { network linked to various back-offices / service modules. }\end{array}$ & KEeLAN (2002) \\
\hline
\end{tabular}

Table 1 E-Government Incremental Progressions Studied in Literature Adapted and expanded from Irani et al. (2005)

Not only the numbers but also the stages of e-government progressions shift from national to local (Gil-Garcia and Martinez-Moyan, 2005). However, there seems to be a general agreement in literature about the incremental approach. Either four or five stages are preferred (Torres et al., 2004).

\section{Research Methodology}

This research draws on KEeLAN methodology. There are two reasons behind this choice. First, it reflects European Union's criteria about a model of indicators and a list of services used for establishing the advancement level of e-government in member countries. Therefore it suits our benchmarking dimension as a tool. Second, it complies with the e-Europe framework of which Turkey is also a part.

KEeLAN is an acronym for Key Elements of Electronic Local Authorities' Network. It is one of the many projects undertaken through e-Europe research activities, also known as 
“Framework Programs”. These programs lay out the precedence for the EU's research agenda, covering a wide range of technological development and demonstration activities. The KEeLAN research is divided into two phases; measuring the e-government stages and back-office developments. The e-government stages are classified by six categories (KEeLAN, 2002):

Stage 0 - No web presence,

Stage 1 - Information: online information about public service,

Stage 2 - Interaction: downloading forms,

Stage 3 - Two-way interaction: processing of forms, including authentication,

Stage 4 - Transaction: full case handling (decision and delivery with payment),

Stage 5 - Service Integration: online service delivery enabled by means of a secured network linked to various back-offices / service modules.

The websites of the Turkish local governments were scanned by the web-scanning tool developed and disseminated on the KEeLAN research website (http://www.keelan.ie/). The tool is composed of a list of questions related to the basic services and subservices in table 2 . The idea is to check the levels of aforementioned stages of those services through measuring their interactivity progression:

a) Request and application: Covers the level of interactivity of the website of the local authority by addressing issues related to uploading and downloading of information / application forms, availability of information and modalities of interaction, etc.

b) Handling: Covers the response to external demand by addressing issues related to reply time and modality of reply to a request, accessibility of databases (editing and monitoring of data), etc.

c) Help: Covers the level of interactivity and modalities of support.

d) Modality of appearance: User-interface features of the website supporting service delivery.

Actually, these service provisions were 12 in total but in order to deal with a sufficient amount of public services nine basic services were defined along with their sub-services and included into the tool (KEeLAN, 2002). 
Arslan, A. (2008). Assessment of the Turkish Local e-Governments: An empirical study. International Journal of Human Sciences [Online]. 5:2. Available: http://www.insanbilimleri.com

\section{SERVICES}

Policy making

The service on 'policy making' involves the degree in which stakeholders are involved in the decision making process by the local authority / council, supported by the website.

\section{Economic development}

This service on 'economic development' involves support for companies and consists of the following sub-services:

- finding employees

- $\quad$ finding buildings / properties

- $\quad$ finding companies in the area

- $\quad$ finding and applying for grants

- submitting/querying tax declaration

- $\quad$ online payment

\section{Personal documents}

This service on 'personal documents' involves application for documents / life-events and consists of the following subservices:

- requesting passport

- requesting driver’s license

- requesting ID card

- requesting/ querying birth / marriage certificate

\section{Credit and loans/financial support}

This service on 'credits and loans' involves financial support for citizens and consists of the following sub-services:

- $\quad$ applying for unemployment benefits

- applying for child allowance

- $\quad$ applying for student grants

- $\quad$ applying for financial support for medical costs

- submitting/querying tax declaration online payment

\section{Education}

The service on 'education' involves support for students on enrolment and monitoring of results and consists of the following sub-services:

- enrolment in schools

- $\quad$ enrolment in university

- monitoring exam results

\section{Building permits}

This service on 'building permits' involves support for companies and citizens in acquiring permits, and consists of the following sub-services:

- monitoring planning

- $\quad$ applying for building permission

- $\quad$ querying for cadastral planning

\section{Environment}

The service on 'environment' involves support for companies and citizens in applying for permits and controlling their waste-management and consists of the following sub-services:

- $\quad$ applying for permits 


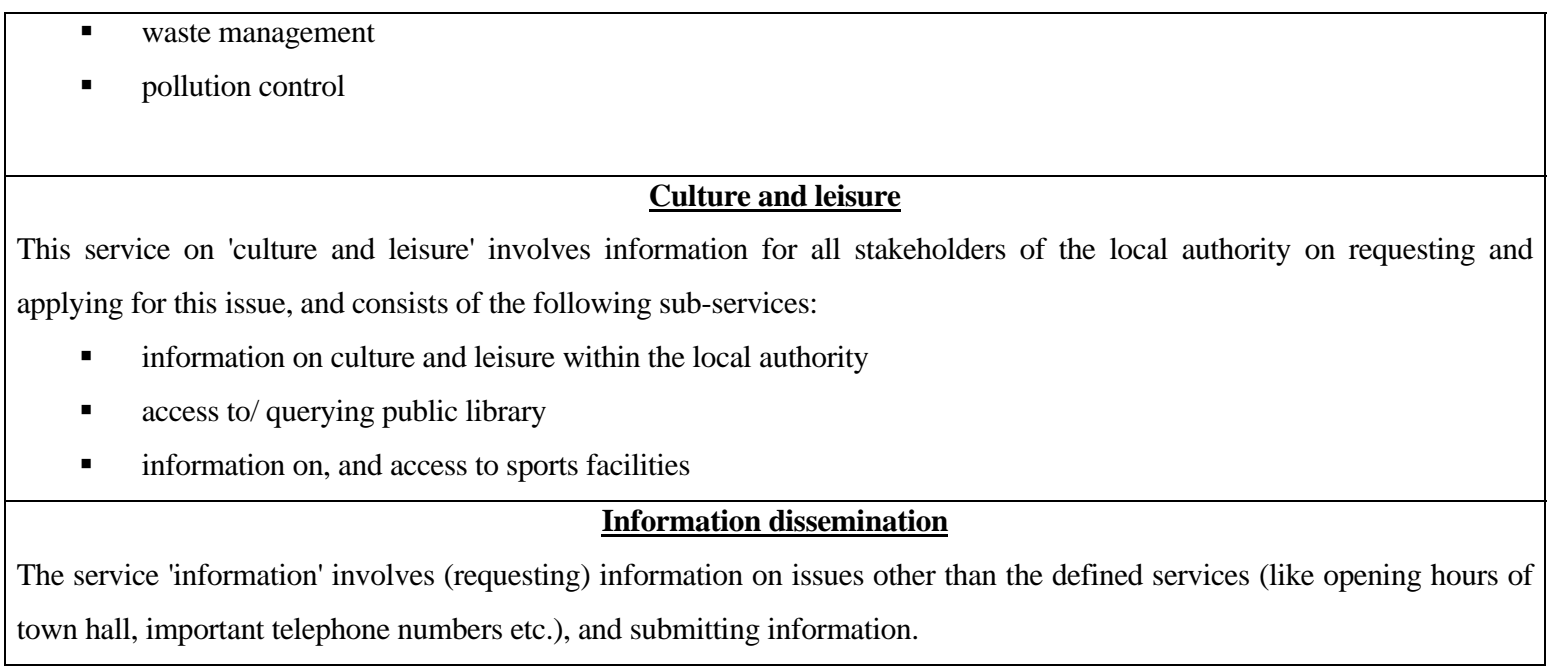

\section{Table 2 The Services and subservices Measured by the Web-Scanning Tool}

Depending on the depth of interactivity the tool automatically computes a score (score for generation) that indicates the stage of the corresponding service. (For a detailed computation methodology check the relevant website: http://www.keelan.ie/)

Following the web scanning process, 20 of those local authorities were invited for online indepth interviews to explore and clarify some certain issues like unexpected high stages or visa versa.

\section{Analysis of the Findings and Discussions}

It took seven months (July 2005 to March 2006) to complete the web scanning process and an additional two months to evaluate the results.

During the study period there were 969 websites out of 3228 local governments (30, $01 \%$ ). And from these, 104 (10, 7 \%) were offering certain basic services on their websites. But at the end of web scanning, we found that 63 (60, $6 \%$ ) websites seems to be functioning. The rest was either temporarily out of order or not operating at all. The tool computed the egovernment stages for each service of these 63 local authorities.

All the results are collected into table 3. The European authorities' calculations are also included to compare and to give a broader perspective. 
Arslan, A. (2008). Assessment of the Turkish Local e-Governments: An empirical study. International Journal of Human Sciences [Online]. 5:2. Available: http://www.insanbilimleri.com

\begin{tabular}{|c|c|c|c|c|c|c|c|c|c|c|c|}
\hline Country & $\begin{array}{l}\text { Number of } \\
\text { Authorities } \\
\text { Scanned }\end{array}$ & $\begin{array}{l}\text { Policy } \\
\text { making }\end{array}$ & $\begin{array}{c}\text { Economic } \\
\text { development }\end{array}$ & $\begin{array}{c}\text { Personal } \\
\text { documents }\end{array}$ & $\begin{array}{c}\text { Credits } \\
\text { \& } \\
\text { Loans }\end{array}$ & Info. & Edu. & $\begin{array}{l}\text { Building } \\
\text { permits }\end{array}$ & Envir. & $\begin{array}{c}\text { Culture } \\
\& \\
\text { Leisure }\end{array}$ & $\begin{array}{c}\text { Means } \\
\text { per } \\
\text { country }\end{array}$ \\
\hline $\begin{array}{l}\text { UK/Northern } \\
\text { Ireland }\end{array}$ & 4 & 1,00 & 1,33 & - & - & 1,67 & - & - & - & 2,00 & 1,47 \\
\hline Spain & 68 & 1,48 & 2,18 & 1,64 & 2,29 & 2,45 & 2,00 & 1,53 & 1,20 & 1,43 & 1,81 \\
\hline Belgium & 45 & 2,18 & 1,83 & 2,27 & 1,67 & 2,16 & 1,22 & 1,00 & 1,93 & 1,84 & 1,83 \\
\hline Luxembourg & 10 & 1,60 & - & 2,70 & - & - & - & - & 2,00 & 2,20 & 2,20 \\
\hline Greece & 20 & 1,40 & 3,00 & 2,29 & 2,00 & 2,24 & - & 1,67 & 1,17 & 1,75 & 1,97 \\
\hline Turkey & 63 & 2,08 & 3,84 & 3,00 & 3,82 & 3,51 & - & 3,00 & - & 2,49 & 3,11 \\
\hline Portugal & 20 & 1,47 & 2,40 & - & - & 2,30 & - & 3,50 & 2,40 & 1,63 & 2,26 \\
\hline Austria & 20 & 2,05 & 2,40 & - & - & 2,95 & - & - & - & 1,90 & 2,30 \\
\hline UK/England & 77 & 2,42 & 2,19 & 1,83 & - & 2,88 & 1,75 & 2,63 & 1,65 & 2,36 & 2,30 \\
\hline $\begin{array}{l}\text { The } \\
\text { Netherlands }\end{array}$ & 45 & 2,36 & 2,50 & 2,21 & 2,41 & 2,32 & & 2,08 & 2,05 & 2,21 & 2,36 \\
\hline Italy & 90 & 1,91 & 2,50 & 2,10 & 2,60 & 2,68 & 2,80 & 2,63 & 2,44 & 2,51 & 2,41 \\
\hline Germany & 90 & 2,20 & 3,25 & 2,13 & - & 2,67 & & 2,76 & - & 2,16 & 2,52 \\
\hline UK/Scotland & 6 & 2,33 & 1,00 & - & - & 2,83 & & 2,60 & - & 3,40 & 2,53 \\
\hline Sweden & 45 & 2,40 & 3,50 & - & - & 2,89 & 2,00 & 1,88 & 1,50 & 3,65 & 2,59 \\
\hline Finland & 21 & 3,05 & 1,75 & - & 2,00 & 3,00 & - & 2,40 & - & 3,62 & 2,69 \\
\hline UK/Wales & 3 & 2,67 & 2,00 & - & - & 3,00 & - & 3,50 & 2,00 & 2,00 & 2,69 \\
\hline France & 90 & 2,36 & 3,00 & 2,87 & - & - & - & - & 2,38 & 2,47 & 2,69 \\
\hline Denmark & 21 & 2,48 & - & 2,67 & 3,89 & 2,69 & 1,00 & 2,22 & 2,50 & 3,84 & 2,71 \\
\hline Ireland & 20 & - & - & & 3,68 & - & - & 3,65 & 3,60 & 2,74 & 3,12 \\
\hline \multicolumn{2}{|c|}{ Standart deviation } & 0,51 & 0,77 & 0,43 & 0,86 & 0,44 & 0,64 & 0,79 & 0,64 & 0,72 & 0,43 \\
\hline
\end{tabular}

\section{Table 3 The Overall Results of E-government Stages for the Basic Services}

The means of stages for each country are presented in figure one. Ireland and Turkey have the highest means for the sophistication of e-services. The highest mean for Turkey is caused by highest stage levels from three services; economic development $(3,84)$, personal documents (3), and credit \& loans (3, 82).

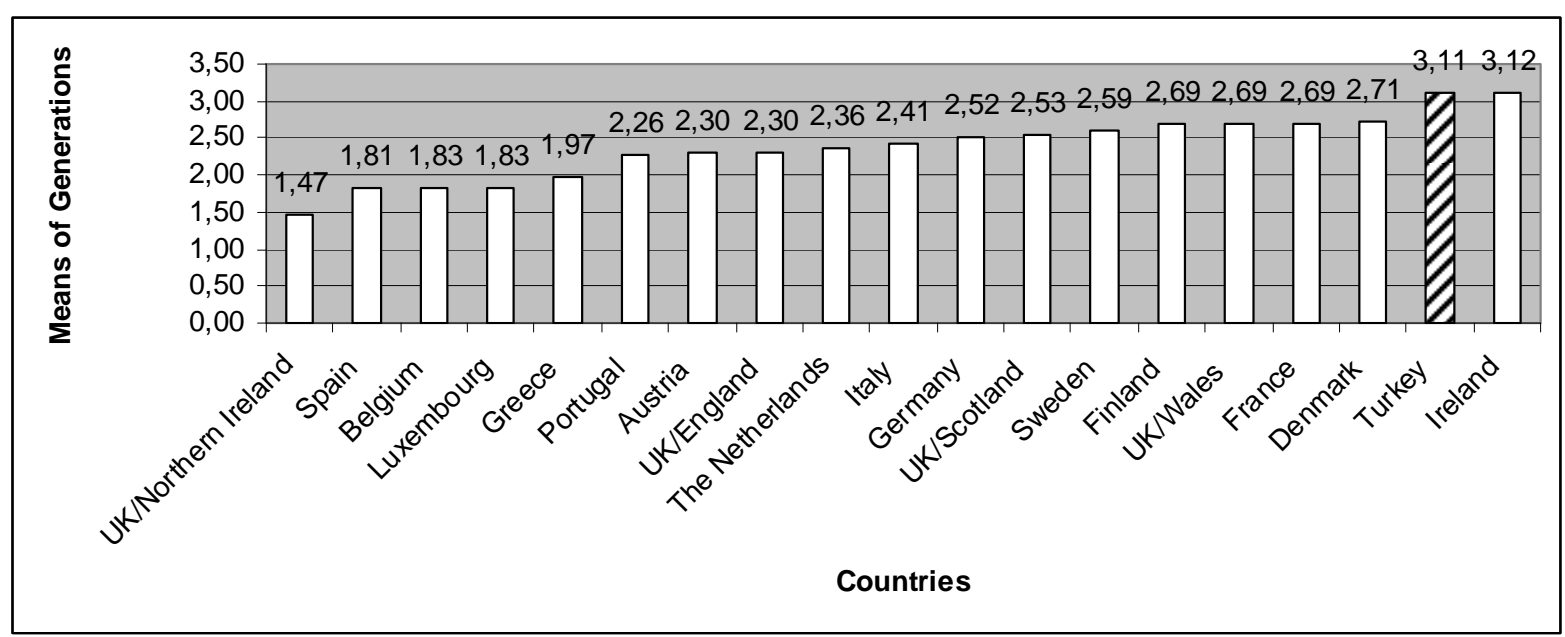

Figure 1 The Means of Front Office Performances Per Country 
The means in figure two suggest that the promise of democracy through e-government in Turkish local administrations requires quite a long way to be realized. Hence, the scanning sessions yielded three important issues; four of the authorities stated the fact about digital exclusion in their jurisdictions (low computer usage), five expressed the general unwillingness of the public interest in regional politics and pacifism; lastly, six of the local jurisdictions admitted the immersed pressure coming from the citizens for economic related service provisions. After finishing transformation of managerial processes yielded in enhancement of economic revenue, they started to put other services (democracy and culture) online. This situation reminds theories (Moon's, 2002; Wescott, 2002; West, 2004) about the fifth stage in evolution of e-government. The last stage is representing participative democracy. Turkish Local e-governments are following the same path. During the scanning period, ten of the local governments with high stage levels from the services like economic development, personal documents, and credit \& loans, initialized a diversity of online cultural and social activities including certain political topics.

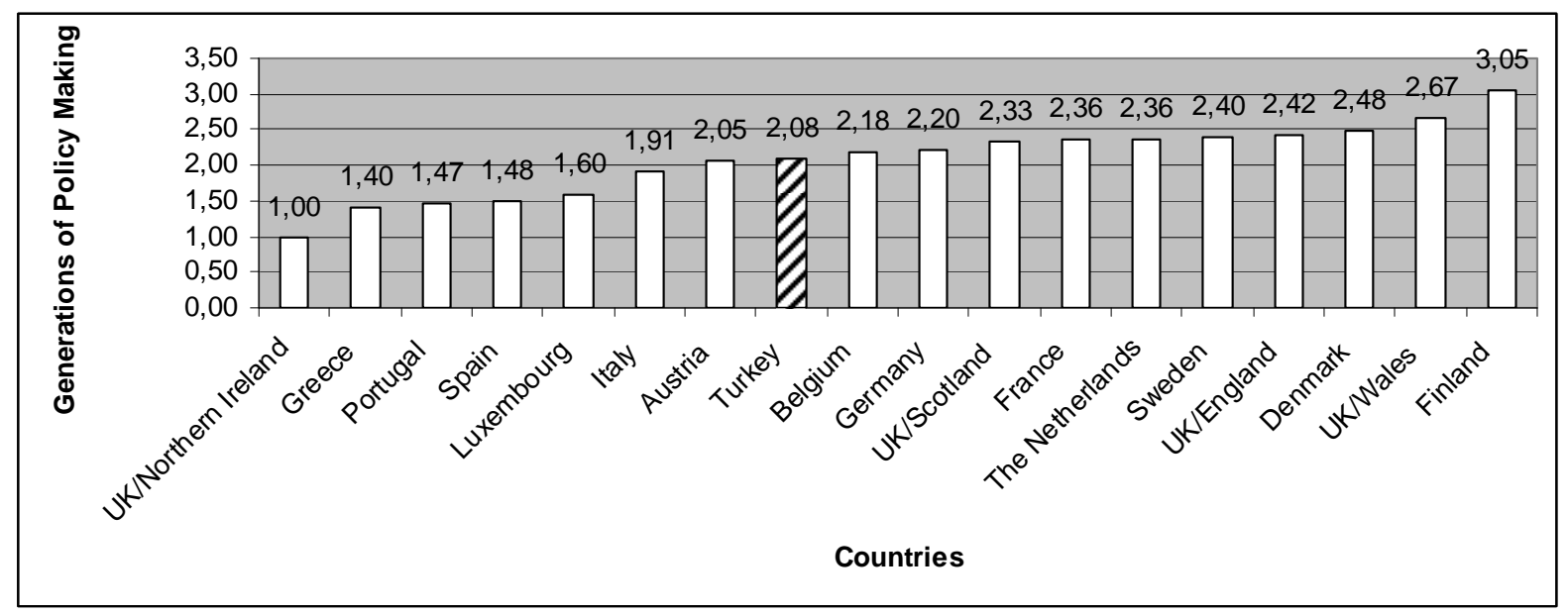

Figure 2 Policy Making Performances

The education system is centralized in Turkey. So, the level of stage for educational services was not available. In Europe, Italy leads the top country in that element. However, there are certain areas of online opportunities for the local administrations waiting to be exploited; such as shared portals supplying information about local schools, types of schools, number of teachers, students per class, schools' capabilities, performances, etc. 


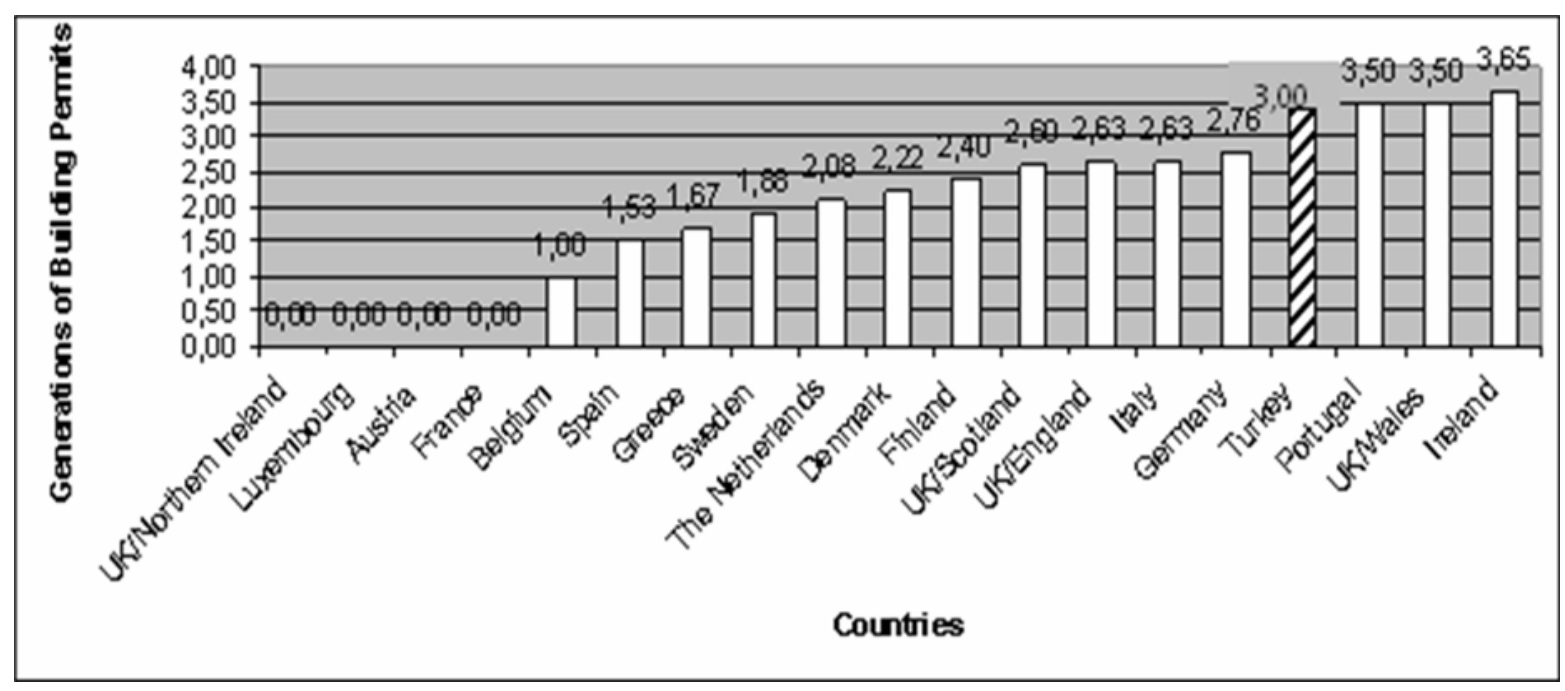

Figure 3 Performances of Building Permit Services

The stage level for building permits are mainly comprised of look-up and online application of those services (Figure 3). There are ongoing efforts of setting a common ground for interoperability issues among the related parties such as municipalities, subsidiaries of central government on cadastral issues and General Command of Mapping (National Geographic Informaton System [NaGIS] Action Report, 2005). According to a recent research by TurkStat (2006a) on Municipal City Information System Research among the Turkish municipalities pointed that $21 \%$ installed Geographical Information Systems in their jurisdictions. Differences in data exchange models and the low use of e-signatures are the main obstacles before the full realization of these services online.

Except for seven local governments, providing only downloadable documents about the environmental issues online, the Turkish local e-governments performed poorly. However, some specific issues like waste water and solid waste (from homes and industries; organic/inorganic, chemicals, medical, etc.) are dealt under intermixed topics. For example waste water events are processed through the general water topics and there are many stage four e-services in this respect (57 out of 63). Hence, a single topic on environment was hard to find during the web scanning phase. Applications regarding waste management issues are made both by phones and e-mail/e-forms to online clearing desks.

Online e-services on culture and leisure were not prevalent among the Turkish authorities. As mentioned before, the priority of e-service provisions was economic rather than cultural or social. Although there are good examples of cultural matters like looking up public libraries (District of Kadıköy, İstanbul Metropolitan), making reservations and online 
payment for theatre plays (İstanbul Metropolitan), there is still a long way to be covered (Figure four). When asked to those municipalities the main drivers behind these online cultural activities, all told that the push came from down-to-top, from the citizens; two of these authorities suggested a high level income and a high rate of literacy in their regions.

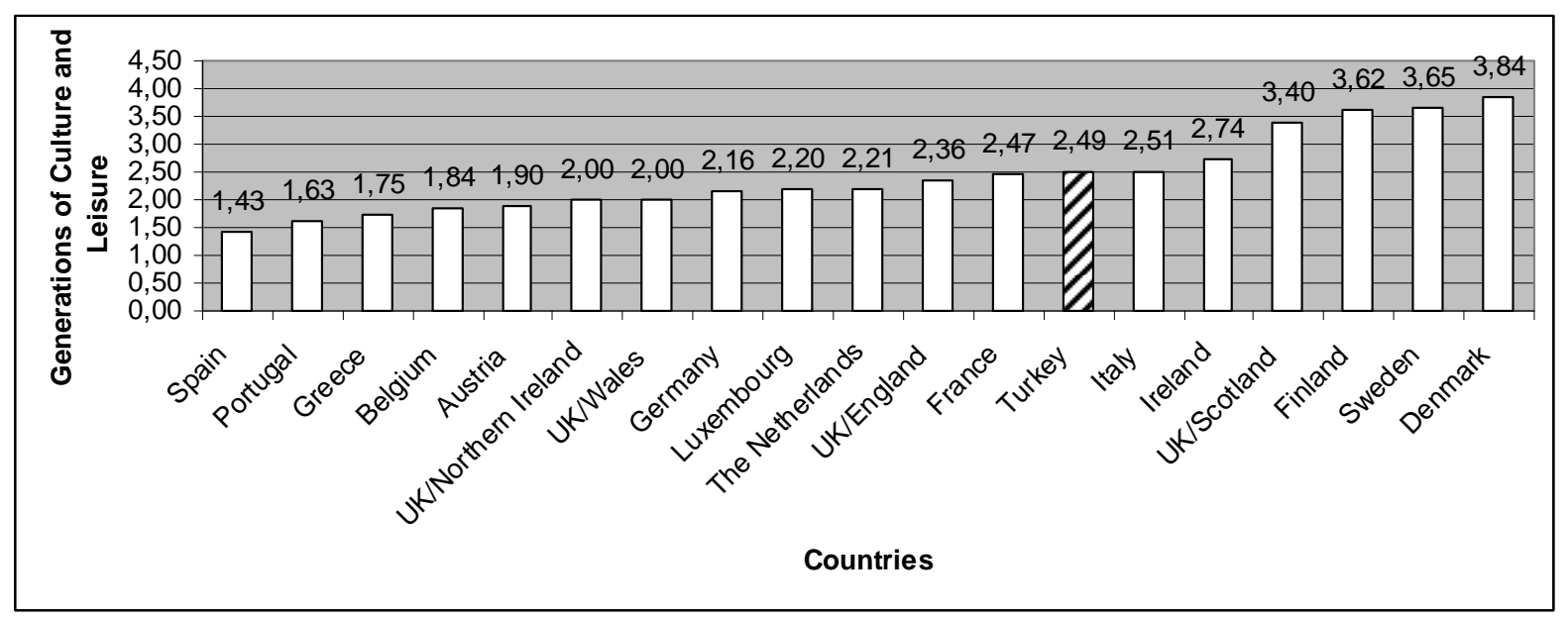

Figure 4 Performances of Culture and Leisure Services

Information dissemination was the most common feature among the basic services of the Turkish local authorities (Figure five). As political entities, the local governments show a high tendency for using the web merely as a content publishing tool. We argue that the reasons for the highest stage level on the Information dissemination are two-fold. Firstly, the law on information freedom obliges every public entity to provide related information. Either downloadable or filled online, through any type of media (paper mail, fax or e-mail) information should be provided to the citizens. And next, the high rate of updating information on the websites of the Turkish local initiatives. Out of 63 scanned websites, 44 (68, $94 \%$ ) updates their content on a daily basis. Similar result came from TurkStat research (2006b); among 424 municipalities 260 (61, $32 \%$ ) declared that updates on content occurs on daily and weekly basis. 


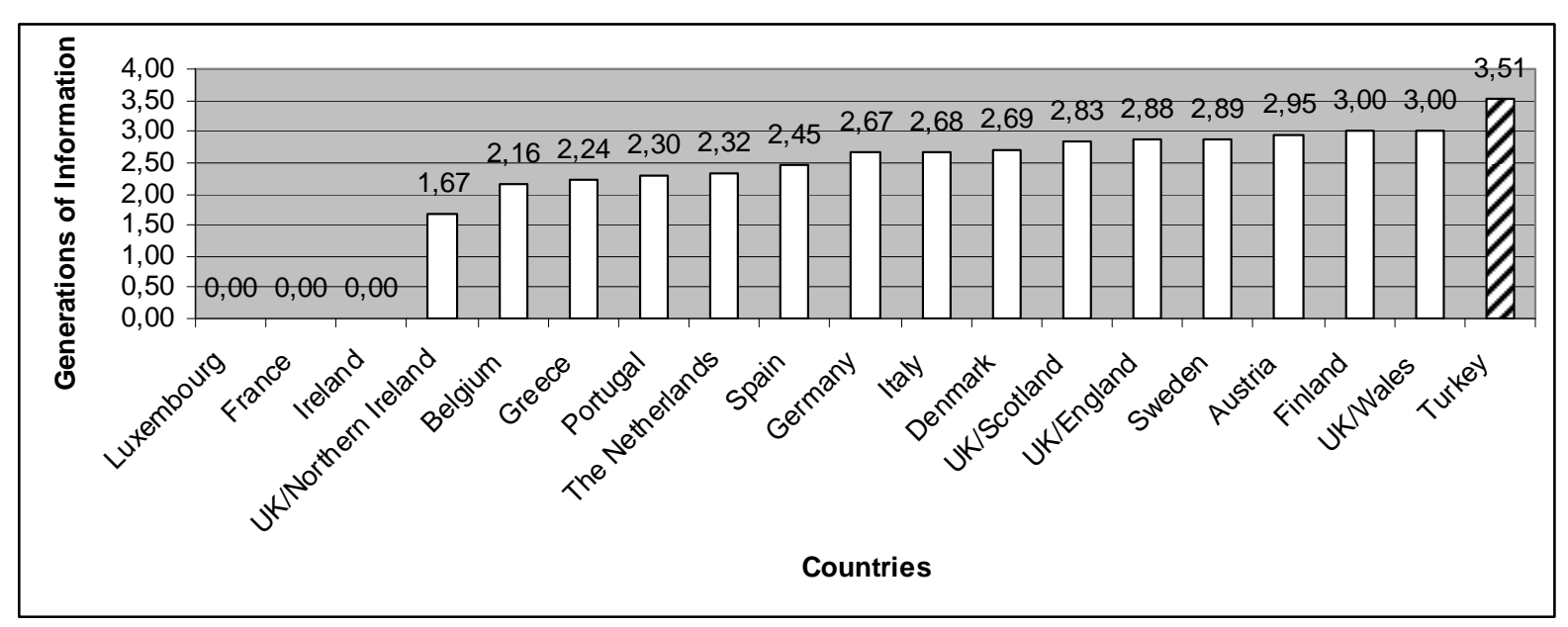

Figure 5 Performances of Information Dissemination

Although not included as a separate service among the context of e-Europe Basic Services, usability is also one of the most important features of websites. It focuses on and addresses logic-design of software applications and services to ease of mental comprehension for all type of users; even these practices become good accessibility practices (Criado \& Ramilo, 2003). It is one of the "highly significant issues and need due consideration in the planning, development and implementation process of e-government” (Choudrie et al., 2004: 582). The performance of the Turkish local administrations regarding the usability issues is average (Figure six). The main reason for the high scores of the Member Countries on usability may be found in the way they approach to these topics. The usability and accessibility issues are considered as the primary factors of their national strategies for egovernment websites (England, Scotland, Finland). But for the Turkish Local Governments, all of the scanned websites have problems on usability as much as accessibility. This gives rise to the debate of digital divide. Impaired and older citizens, children, and women are not totally considered during the design procedures of the websites. Given to the fact that websites are the front offices of the local governments, in other words, the first time confrontation desks, these issues should be carefully elaborated. 


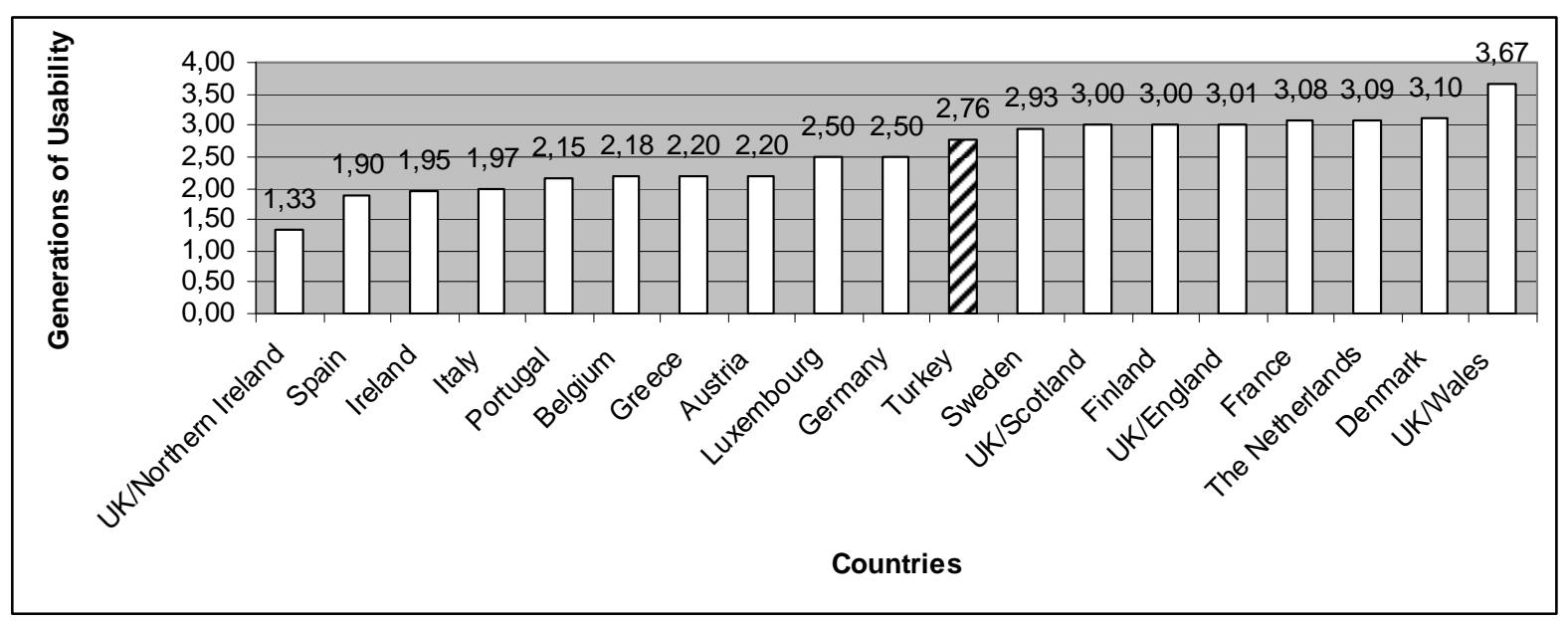

Figure 6 Performances of the Website Usability

The overall results of the Turkish Local e-Government stages are demonstrated in figure seven. The average is relatively high given to the fact that other high levels from economy related services. To take a closer look and to make a sound comparison, the means of all stages are given in figure eight. Educational and environmental service levels couldn't be measured for the Turkish side. However, five service stages for economic development, personal documents, credits and loans, information, and building permits are significantly higher than their counterparts. This suggests that these service levels were at the third stage or offering two-way interaction e-services. Meanwhile, European local administrations offer mainly one-way interaction or stage two e-services.

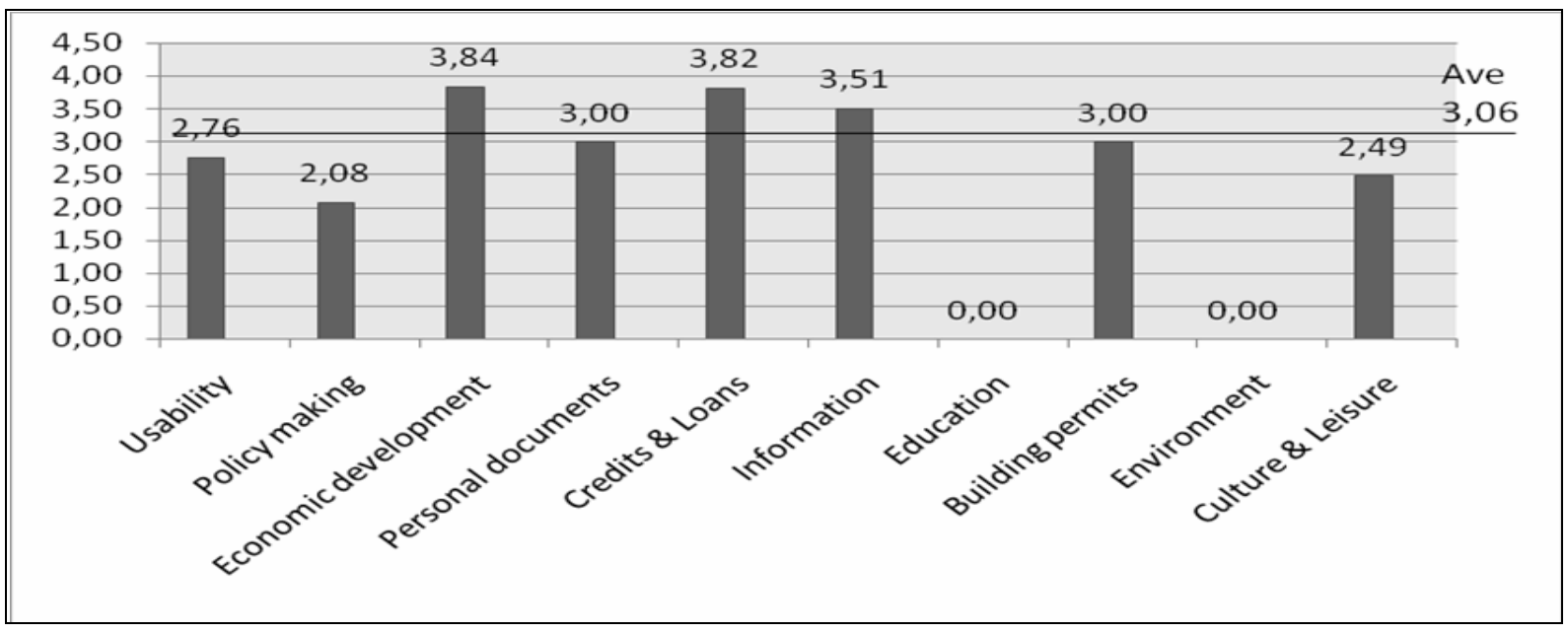

Figure 7 The Overall Stage Levels of the Turkish Local e-Governments

The high levels of online economic services imply that local authorities are looking for ways to decrease the cost of providing services while simultaneously enhancing their efficiency. 
And investing on high volume services to justify by great economic gains is also consistent with literature (Christiansen et al., 2003; Arslan, 2006). This is rather logical for the Turkish local governments because they are facing more constraints in their attempts to implement egovernment projects than the central governments. But on the other hand, as it was stated in the literature earlier by Ho (2002), the focus might be rather internal, considering managerial operating efficiency and enhancing internal communication through ICTs.

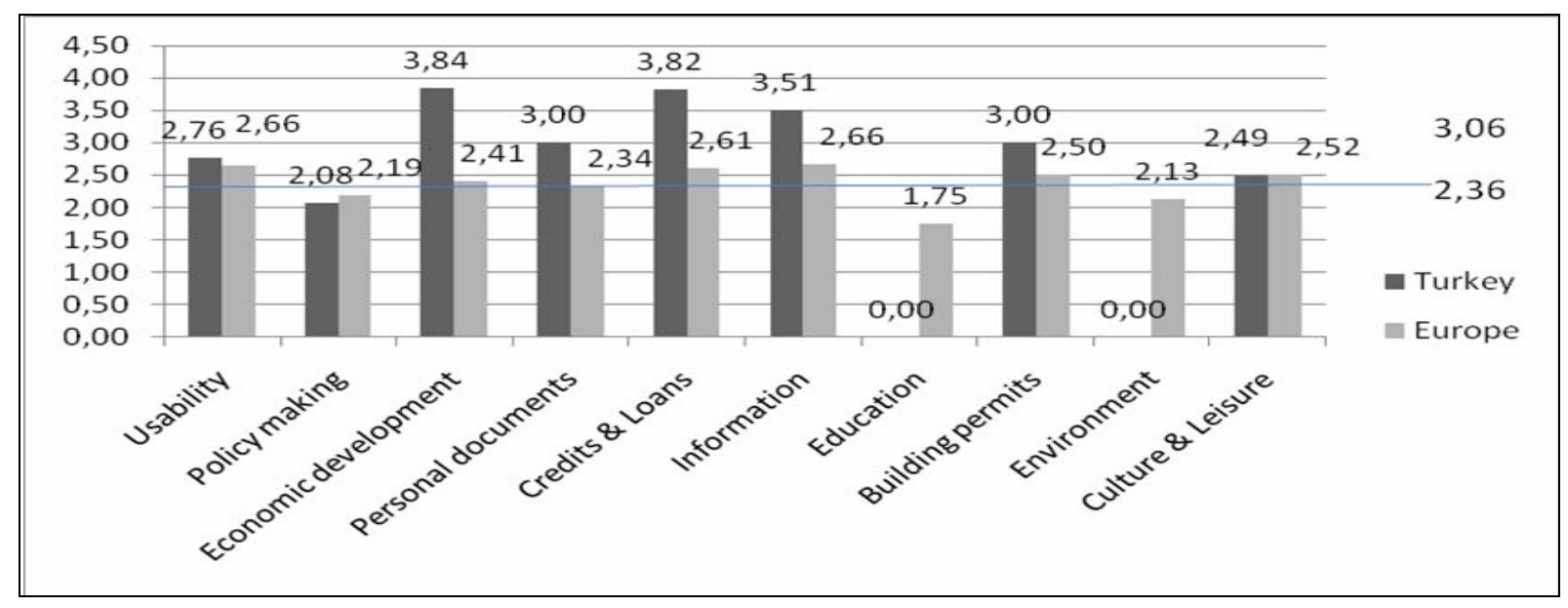

Figure 8 Overall Comparison of Front Office Performances on Service Levels

\section{Conclusions}

Supplying good content and information alone will not suffice. Sophisticated services on cultural and social life events should be reviewed and revised with more consideration. There were good examples (Ten websites), yet not as many as the European ones.

We have witnessed wide discrepancies among municipalities regarding the scope and the quality of e-government initiatives during the scanning sessions. We argue that this is partly due to the financial power used for accommodating qualified personnel and sufficient resources for online service provisions; bigger means better. Likewise, follow up online interviews with the authorities presented a bulk of barriers like interoperability issues between agencies, technology and organizational incompatibility, security, regulations, culture, and legality issues. Often, having a website is considered as enough or worst, only online presence was seen as e-government itself.

The interview sessions evoked another important topic. Most of the local authorities outsourced their e-services. In-house e-service development processes were very rare (2 out of 20 interviewed). There is a need for an urgent coordination mechanism for the local authorities to guide them during the process of e-government projects. Eventually, some 
Arslan, A. (2008). Assessment of the Turkish Local e-Governments: An empirical study. International Journal of Human Sciences [Online]. 5:2. Available: http://www.insanbilimleri.com

institutions assumed this role but the way they handle and lead is questionable. They also lack in qualified personnel, funding, and in the terms of other available sources (Such as the Directorate of Local Administrations, YerelBilgi [Local-Info], YerelNet [Local Net]).

Additional research in this area is necessary to shed more light on the subject and to examine the process in a longitudinal perspective. The future research also needs to expand to supply local authorities with some more concrete guidance and methodologies from different disciplines. Particularly, the citizen side (demand) is a fertile area waiting for the keen researchers.

\section{References}

AAC. (2003). “Strong Municipalities - Europe’s driving force”. The Austrian Association of Municipalities in Austria and in Europe. Publisher: Austrian Association of Communities, Austrian Association of Municipalities, 1010 Wien, Loewelstrasse 6 (July 2003). Retrieved January 15, 2004, from http://www.gemeindebund.at/rcms/upload/ 7_60_1_eng.pdf? PHPSESSID=4d06702900d1995e954eb5a331e0da2d.

Arslan, A. (2006). "KEeLAN: Assessment of Turkish Local Authorities' Front Offices on the Internet through the Context of eEurope Basic Services to Determine the eGovernment Stages and Back Office Integration of the Best-Practices Based on the EFQM Key Elements”. Unpublished PhD Dissertation. Marmara University, Department of Management and Organization Sciences.

Aydemir, S. R. (2003). Hizmette Halka Yakınlık İlkesi (Subsidiarity) ve Türkiye’de Merkezi Yönetim ile Yerel Yönetimler Arası Yetki ve Görev Bölüşümü. Retrieved September 12, 2005, from www.kutso.org.tr/bilgihizmetleri/ aydemir/hizmet.doc.

Bindebir, S. (2004). "Intergovernmental Finance and Local Government System in Turkey: Experiences and Lessons to be Learned from Poland”. Prepared for Ecomod 2004 International Conference on Policy Modeling. Retrieved June 01, 2005, from www.ecomod.net/conferences/ ecomod2004/ecomod2004_papers/165.pdf.

Chandler, S. \& Emanuels, S. (2002). “Transformation Not Automation”. Proceedings of 2nd European Conference on Egovernment. St Catherine’s College Oxford, UK, pp. 91102. Retrieved April 29, 2004, from http://www.academic-conferences.org/eceg/ eceg2005/2-proceedings-eceg2002.htm.

Choudrie, J., Ghinea, G. \& Weerakkody, V. (2004). Evaluating Global e-Government Sites: A View using Web Diagnostic Tools. Electronic Journal of e-Government. Volume 2 Issue 2, 104-115. Retrieved January 30, 2006, from http://www.ejeg.com/ volume2/volume2-issue2/v2-i2-choudrie-pp105-114.pdf.

Criado, I.J. \& Ramilo, M.C. (2003). E-Government in Practice: An Analysis of Web Site Orientation to the Citizens in Spanish Municipalities. The International Journal of Public Sector Management. Vol. 16 No. 3, 191-218. Retrieved January 30, 2006, from http://www.emeraldinsight.com/0951-3558.htm.

Christiansen, F., J. H. Kraglund, \& J. Steensen (2003). Value Creation in eGovernment projects. An exploratory analysis conducted for the Danish presidency of the eGovernment workgroup of the Directors General. Retrieved June 12 , 2004, from http://e.gov.dk/uploads/ media/Value_Creation_in_eGovernment_projects_01.pdf. 
Arslan, A. (2008). Assessment of the Turkish Local e-Governments: An empirical study. International Journal of Human Sciences [Online]. 5:2. Available: http://www.insanbilimleri.com

EU. (2003). Regional and Local Government in the European Union: Foreword. Retrieved May 19, 2006, from http://www.taiex.be/Library/SubNat/RLGinEU/RLGinEU1.htm\#3.

Griffin, D., Foster, A., \& Halpin, E. (2004). Joined-up e-Government: an exploratory study of UK local government progress. Electronic Journal of E-Government, Vol 3, Issue 1, 13-28. Retrieved December 02, 2006, from http://www.ejeg.com/volume-3/vol3iss1/v3-i1-art2-griffin.pdf.

Gil-García, J. R. \& I. J. Martinez-Moyano (2005). Exploring E-Government Evolution: The Influence of Systems of Rules on Organizational Action. NCDG Working Paper No. 05-001. Retrieved March 04, 2007, from http://www.ksg.harvard.edu/digitalcenter/ Research/working_papers/gil-garcia_wp05-001.pdf.

Ho, A.T. (2002). Reinventing Local Governments and the E-Government Initiative. Public Administration Review 62(4), 434-44. Retrieved November 13, 2003, from http://www.public.iastate.edu/ alfredho/ ITR/EGovtLocal_PARfinal.pdf..

Holzer , M., \& S. Kim, (2003). Digital Governance in Municipalities Worldwide; an Assessment of Municipal Web Sites throughout the World .The E-Governance Institute. National Center for Public Productivity. Rutgers, the State University of New Jersey - Newark. Retrieved February26, 2006, from http://andromeda.rutgers.edu/\%7Eegovinst/ Website/Report\%20-\%20031117.pdf

Howard, Mark (2001). e-Government Across the Globe: How Will 'e' Change Government. Government Finance Review, 17(4), pp. 6-9. Retrieved March 10, 2005, from www.gfoa.org/services/gfr/archives/2001/08/gfr0801.pdf.

IDABC Factsheet (2006). "e-Government in Turkey”. e-Government Observatory. A Publication of European Commission Enterprise and Industry Directorate-General. Retrieved 19 March 2007, from http://ec.europa.eu/idabc/egovo.

Irani, Z., P.E.D Love, T. Elliman, S. Jones, \& M. Themistocleous (2005) . Evaluating egovernment: learning from the experiences of two UK local authorities. Information Systems Journal 15 (1), 61-82. Retrieved March 9, 2006, from http://www.blackwell-synergy.com/doi/pdf/10.1111/j.1365-2575.2005.00186.x.

Kavruk, Hikmet (2004). The System of Local Government in Turkey. Gazi Ün. İ.I.B.F. Dergisi, 6. Cilt, 1. Sayl, s.181-205. Retrieved May 24, 2006, from http://dergi.iibf.gazi.edu.tr/pubs.aspx?x=6.

KEeLAN (2002). Key Elements for Electronic Local Authorities’ Networks.WP3: Webscanning of Local Authorities' Front Office on the Web. D4: Report on Use of Internet by Local Governments and Best-Practices (web-scanning results). Retrieved December 10, 2003, from http://www.keelan.ie.

Kunstelj, M. \& Vintar, M. (2004). Evaluating the progress of e-Government development: A critical analysis. Information Polity 9, 131-148, IOS Press. Retrieved May 24, 2006, from http://web32.epnet.com.

Layne, K.and Lee, J. (2001). Developing Fully Functional E-Government: A Four Stage Model. Government Information Quarterly. Vol. 18, pp.122-136. Retrieved June 13, 2004, from http://faculty.maxwell.syr.edu/jpgant/layne_leeGIQ4398832.pdf.

Löfstedt, U. (2005). e-Government - Assessment of Current Research and Proposals for Future Directions. International Journal of Public Information Systems, vol 2005:1, pp.39-52. Retrieved May 24, 2006, from http://www.hia.no/iris28/ Docs/ IRIS20281008.pdf.

Moon, M.J. (2002). The evolution of e-Government among municipalities: Rhetoric or reality? Public Administration Review, 62(4): 424-433. Retrieved June 13, 2004, from http://www.andromeda.rutgers.edu/ ncpp/cdgp/articles/moon-2002.pdf. 
Arslan, A. (2008). Assessment of the Turkish Local e-Governments: An empirical study. International Journal of Human Sciences [Online]. 5:2. Available: http://www.insanbilimleri.com

NaGIS Action Report (2005). Turkish National Geographic Information Systems Structure. Action Plan 47 (Draft in Turkish). Retrieved April 15, 2007, from http://www.tkgm.gov.tr.

Pavlichev, A. (2004). "The Effects Of Internal Characteristics Of Municipal Government Agencies And Environmental Factors Of Municipalities On The Scope And The Quality Of Municipal E-Government Initiatives: Developing An Integrated Approach”. Doctorate Dissertation, Graduate Faculty of North Carolina State University, Public Administration, Raleigh. Retrieved July 7, 2005, from http://www.lib.ncsu.edu/ theses/available/etd-12282004-095954/unrestricted/etd.pdf.

Perfromance Report (2006). E-Dönüşüm Türkiye Çerçevesinde Yürütülen Faaliyetler. Performans Denetim Raporu. T.C. Sayıştay Başkanlığı (In Turkish). Retrieved March 19, 2007, from http://www.sayistay.gov.tr.

The Scottish Office (n.d.) Summary of Devolved Parliaments in the European Union. Unit for the Study of Government in Scotland, University of Edinburgh: August 1998. Publisher The Scottish Office. Retrieved December 30, 2001, from http://www.scotland.gov.uk/ government/ devolution /sdpe-02.asp.

SIG (2006). E-Transformation Strategy Implementation Guide (In Turkish). SPO Publications. Retrieved October 8, 2006, from http://212.175.33.22/index.asp.

Silcock, R. (2001). What is e-Government?. Hansard Society for Parliamentary Government. Parliamentary Affairs, Vol: 54 No:1, pp.88-101. Retrieved March 3, 2003, from http://pa.oxfordjournals.org/cgi/reprint/54/1/88.

Torres, L., V. Pina, \& B. Acerete (2004). "E-governance Developments in EU Cities”. Reshaping Government Relation to Citizens. Retrieved January 13, 2006, from http://www.uc3m.es/uc3m/dpto/EMP/seminar/torres.pdf.

TurkStat (2006a). Municipal City Information System Research, 2005. TurkStat News Bulletin, Number 23, February 6, 2006. Retrieved March 08, 2006, from http://www.bilgitoplumu.gov.tr/eng/docs/ k_060206.xls.

TurkStat (2006b). Municipal Web Services Research, 2005. TurkStat News Bulletin, Number 19, January 31, 2006. Retrieved March 8, 2006, from http://www.die.gov.tr/ENGLISH/ SONIST/DISTICIST/k_310106.xls.

UN - DPEPA Report (2002). “Benchmarking E-government: A Global Perspective”. Assessing the Progress of the UN Member States. Retrieved August 25, 2004, from http://unpan1.un.org/intradoc/groups/public/documents/UN/UNPAN021547.pdf

UNPAN Report (2006). Assessment of Public Administration in Turkey. Retrieved February 20 2006, from http://unpan1.un.org/intradoc/groups/public/documents/UN/UNPAN015909 .pdf

Wescott, C. G. (2003). E-Government in the Asia-Pacific Region. The Asian Development Bank Publications. Retrieved July 10, 2005, from http://www.adb.org/ Documents/Papers/E_Government/egovernment.pdf.

West, D. M. (2004). E-Government and the Transformation of Service Delivery and Citizen Attitudes. Public Administration Review. Vol. 64 No. 1, pp. 15-27. Retrieved August 31, 2005, from http://www.blackwell-synergy.com/doi/abs/10.1111/j.1540-6210. 2004. 00343.x. 